Article

\title{
Selective oxidation of alcohols over copper zirconium phosphate
}

\author{
Abdol R. Hajipour a,b,*, Hirbod Karimi a \\ a Pharmaceutical Research Laboratory, Department of Chemistry, Isfahan University of Technology, Isfahan 84156, Iran \\ ${ }^{\mathrm{b}}$ Department of Neuroscience, University of Wisconsin, Medical School, Madison, WI 53706-1532, USA
}

\section{A R T I C L E I N F O}

Article history:

Received 21 February 2014

Accepted 31 March 2014

Published 20 September 2014

\section{Keywords:}

Copper zirconium phosphate

Selective oxidation

Solid catalyst

Alcohol

\begin{abstract}
A B S T R A C T
The catalytic activity of copper zirconium phosphate (ZPCu) in the selective oxidation of alcohols to their corresponding ketones or aldehydes, using $\mathrm{H}_{2} \mathrm{O}_{2}$ as an oxidizing agent, was studied. The oxidation reaction was performed without any organic solvent, phase-transfer catalyst, or additive. Steric factors associated with the substrates influenced the reaction. The catalyst was characterized using $\mathrm{X}$-ray diffraction, inductively coupled plasma atomic emission spectroscopy, energy-dispersive $\mathrm{X}$-ray spectroscopy, and scanning electron microscopy. It was shown that the interlayer distance increased from 0.74 to $0.80 \mathrm{~nm}$ and the crystallinity was reduced after $\mathrm{Cu}^{2+}$ intercalation into the layers. This catalyst can be recovered and reused three times without significant loss of activity and selectivity.
\end{abstract}

(C) 2014, Dalian Institute of Chemical Physics, Chinese Academy of Sciences. Published by Elsevier B.V. All rights reserved.

\section{Introduction}

$\alpha$-Zirconium phosphate (ZP) is one of the most important inorganic compounds with a layered structure, and it has been used in many fields [1,2]. ZP is a useful ion-exchanger because of its extreme insolubility in water, high thermal stability, and resistance to radiation and abrasion $[3,4]$. The $\mathrm{H}^{+}$of the $\mathrm{P}-\mathrm{OH}$ is the exchangeable site and can be exchanged for divalent or trivalent cations, with appropriate enlargement of the interlayer distance [5-9]. There have been some reports on the catalytic activities of these ion-exchanged materials [9-14].

The selective oxidation of alcohols to the corresponding carbonyl compounds is one of the most important and widely used functional group transformations in fundamental synthetic research and industrial manufacturing. This is because of the extensive use of aldehydes and ketones in the synthesis of various chemicals, vitamins, drugs, and fragrances [15-19]. Benzaldehyde (BzH), which is a typical product of alcohol oxidation, is an important starting material for the preparation of intermediates in the dyestuff, agrochemicals, perfumery, and pharmaceutical industries [18-20]. Various catalysts have been developed for the oxidation of alcohols, using molecular $\mathrm{O}_{2}$ or aqueous $\mathrm{H}_{2} \mathrm{O}_{2}$ as the oxidant, in the presence and/or absence of solvents [15-26]. In the present work, we report an efficient, convenient, and mild procedure for the selective oxidation of alcohols by copper zirconium phosphate (ZPCu); the catalyst was characterized using inductively coupled plasma atomic emission spectroscopy (ICP-AES), X-ray diffraction (XRD), and scanning electron microscopy (SEM).

\section{Experimental}

\subsection{Catalyst synthesis}

All chemicals and solvents were purchased from the Merck Chemical Company and used without further purification. The detailed procedure for the preparation of the catalyst can be found in the literature [2,7-9]; some modifications were made

\footnotetext{
* Corresponding author. Tel: +98-311-3913262; Fax: +98-311-3913252; E-mail: haji@cc.iut.ac.ir This work was supported by the Isfahan University of Technology, Iran. 
to the procedure. $\mathrm{ZP}$ was prepared as follows. $\mathrm{ZrOCl}_{2} \cdot 8 \mathrm{H}_{2} \mathrm{O}(5$ g) was refluxed in $12 \mathrm{~mol} / \mathrm{L} \mathrm{H}_{3} \mathrm{PO}_{4}(50 \mathrm{~mL})$ at $100{ }^{\circ} \mathrm{C}$ for $24 \mathrm{~h}$. The obtained precipitate was filtered off and washed with 0.1 mol/ $\mathrm{L}_{3} \mathrm{PO}_{4}$ until free of $\mathrm{Cl}^{-}$. Finally, the solid was washed several times with distilled water until the $\mathrm{pH}$ was neutral, and dried in an oven at $110{ }^{\circ} \mathrm{C}$ for $24 \mathrm{~h}$ [2]. The final product was ground into a fine powder and its structure was determined using XRD. ZPCu was prepared using an ion-exchange reaction [7-9]. ZP (3 g) was dispersed in deionized water (50 mL) at 50 ${ }^{\circ} \mathrm{C} . \mathrm{Cu}(\mathrm{OAc})_{2}$ solution $\left(0.1 \mathrm{~mol} / \mathrm{L}, 100 \mathrm{~mL}\right.$, excess of $\left.\mathrm{Cu}^{2+}\right)$ was added to the dispersion and it was refluxed for $4 \mathrm{~d}$. The acetate ion effectively acts as a base to keep the hydrogen ion concentration in the solution low enough to achieve high loadings [6]. Complete exchange between the cations and the hydrogens of the $\mathrm{P}-\mathrm{OH}$ groups cannot be achieved in less than $3 \mathrm{~d}$ or below $80{ }^{\circ} \mathrm{C}$ [27]. The slurry was hot filtered, and the obtained light-blue solid was washed with distilled water until no $\mathrm{Cu}^{2+}$ was detected in the washing solution (the filtrate was colorless). Finally, the product was dried at $100{ }^{\circ} \mathrm{C}$ for $24 \mathrm{~h}$ and calcined at $600{ }^{\circ} \mathrm{C}$ for $5 \mathrm{~h}$. The final pale-blue product, copper zirconium phosphate $\mathrm{CuZr}\left(\mathrm{PO}_{4}\right)_{2}$, was denoted by $\mathrm{ZPCu}$ (Scheme 1).

\subsection{General experimental procedure for oxidation reaction}

A substrate (5 mmol) and ZPCu (5 mol\%) were added to a $25 \mathrm{~mL}$ two-necked flask. The flask was heated in an oil bath to $60{ }^{\circ} \mathrm{C}$ and then $30 \% \mathrm{H}_{2} \mathrm{O}_{2}$ (0.015 mol) was added slowly, with continuous stirring, over a specified time. The reaction progress was monitored using gas chromatography (GC). When the reaction was complete, the reaction mixture was cooled to room temperature and the catalyst was removed by centrifugation. The organic layer was then separated from the aqueous phase by extraction with $n$-hexane and dried over anhydrous $\mathrm{CaCl}_{2}$. The reaction products were identified GCmass spectrometry (MS) and ${ }^{1} \mathrm{H}$ nuclear magnetic resonance (NMR) spectroscopy.

\section{Results and discussion}

\subsection{Catalyst characterization}

The chemical compositions of ZPCu samples obtained at different stages of the catalyst synthesis (before and after the catalytic reaction) were determined using ICP-AES (PerkinElmer ICP-AES $7300 \mathrm{dv}$ spectrometer). The results are shown in Table 1. Energy-dispersive X-ray spectroscopy (EDS; Zeiss EVO, operated at $20 \mathrm{kV}$ ) was also used to determine the chem-

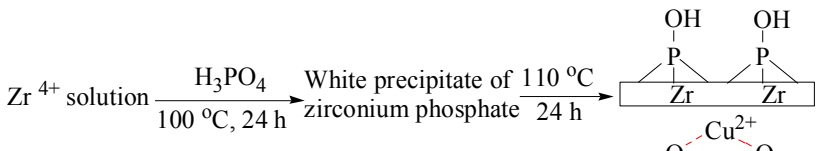

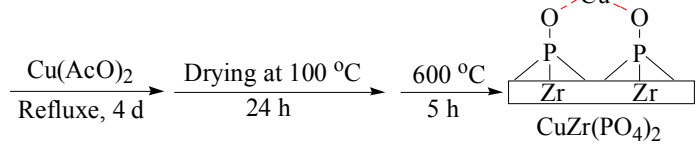

Scheme 1. Summary of ZPCu preparation.
Table 1

Elemental contents of copper zirconium phosphates.

\begin{tabular}{lcrccc}
\hline \multirow{2}{*}{ Entry } & \multirow{2}{*}{ Sample } & \multicolumn{5}{c}{ Elemental content (atm\%) } \\
\cline { 3 - 6 } & & $\mathrm{Cu}$ & 0 & $\mathrm{Zr}$ & $\mathrm{P}$ \\
\hline 1 & $\mathrm{ZP}$ & - & 63.1 & 13.6 & 23.3 \\
2 & $\mathrm{ZPCu}$ & 11.7 & 58.7 & 10.9 & 18.8 \\
3 & $\mathrm{ZPCu}^{\mathrm{a}}$ & 11.1 & 57.6 & 11.6 & 19.7 \\
4 & $\mathrm{ZPCu}^{\mathrm{b}}$ & 11.5 & 59.3 & 10.5 & 18.7 \\
5 & $\mathrm{ZPCu}^{\mathrm{c}}$ & 8.6 & 62.1 & 11.7 & 17.6 \\
\hline
\end{tabular}

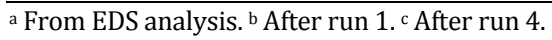

ical composition of ZPCu. The results are shown in Fig. 1 and Table 1 (entry 3).

The results were comparable with earlier one $[4,8,9]$. There was negligible leaching of copper ions into the reaction medium (after first use).

Figure 2 shows the powder XRD (Philips X'pert) patterns of the prepared ZP and ZPCu. They show characteristic reflections in the $2 \theta$ range $0^{\circ}-40^{\circ}$. The diffraction peak of $\mathrm{ZP}$ at $\sim 12^{\circ}$ was assigned to a $d_{002}$ planar basal spacing of $0.75 \mathrm{~nm}$, which was consistent with the previously reported patterns of ZP and derivatives, with a hexagonal crystal system [2]. Figure 2 shows that the $d$-spacing of the (002) plane of ZPCu was larger, which implies that $\mathrm{Cu}^{2+}$ intercalated into the ZP interlayers and increased the $d_{002}$ basal interlamellar spacing of ZP from 0.75 to $0.80 \mathrm{~nm}$.

It is well known that the radii of $\mathrm{Cu}^{2+}(0.072 \mathrm{~nm})[28,29]$ and hydrated $\mathrm{Cu}^{2+}(0.419 \mathrm{~nm})$ [30] are smaller than the basal spacing of $\mathrm{ZrP}(0.75 \mathrm{~nm}) . \mathrm{Cu}^{2+}$ was therefore inserted into the $\mathrm{ZP}$ interlayers, increasing the basal spacing of the modified ZP

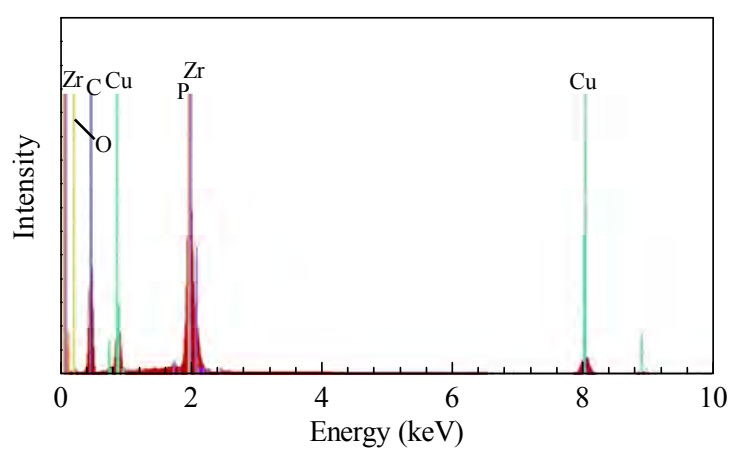

Fig. 1. EDS spectrum of ZPCu sample.

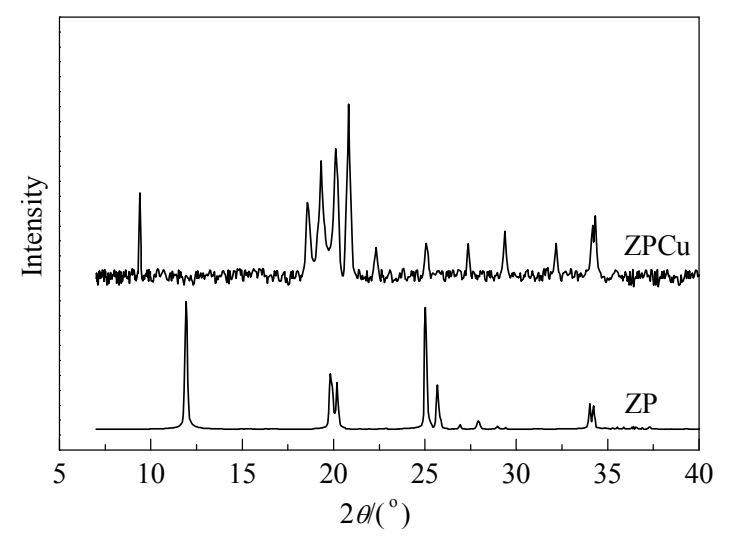

Fig. 2. XRD patterns of powder ZP and ZPCu. 


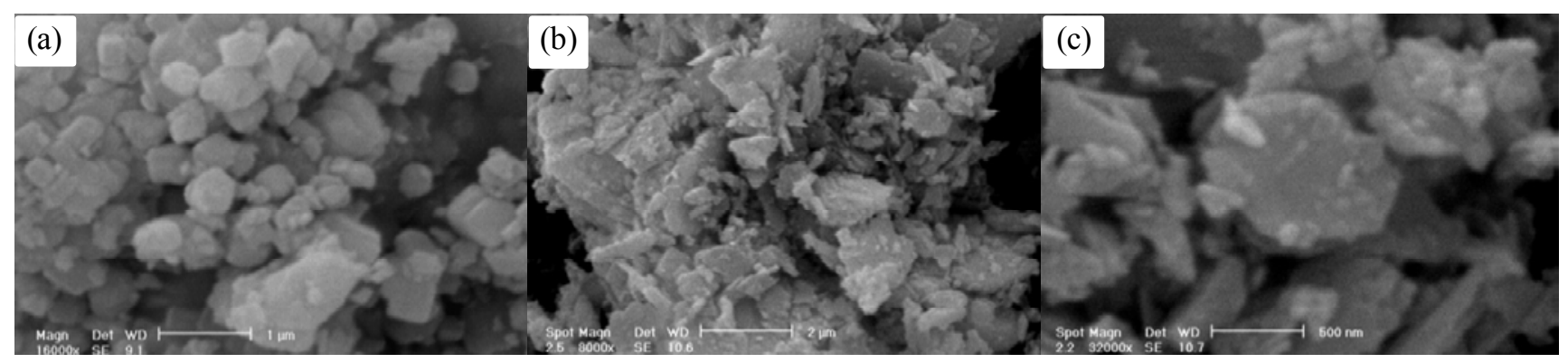

Fig. 3. SEM images of prepared ZP (a) and ZPCu (b, c) samples.

after ion exchange [7-9]. We concluded from the above data that ZPCu was formed. The surface morphologies of ZP and ZPCu were studied using SEM (Philips XL). As shown in Fig. 3, ZP shows hexagonal plates and disks with well-defined shapes and very smooth surfaces. For ZPCu catalyst, it is much less ordered than ZP and fund some aggregation of ZPCu particles in sheets and spheres, and conglomerates with uneven shapes and sizes.

\subsection{Oxidation reaction and expected mechanism}

Benzyl alcohol (BzOH) was selected as the model substrate for determining the optimum conditions; the results are summarized in Table 2. Although the major product was $\mathrm{BzH}$, benzoic acid was also formed as a side product (Table 2, entries 3 , $6,9,11,12$ ). It was found that the selectivity and/or yield were changed by the reaction parameters, i.e., time (Table 2, entries 1-3), molar ratio (Table 2, entries 4-6), temperature (Table 2, entries 7-9), or molar percentage of catalyst (Table 2, entries 10-12). It shows that increasing the temperature initially accelerated the reaction (up to $60{ }^{\circ} \mathrm{C}$ ), but further increases resulted in a decrease in the yield, possibly because of self-de-

Table 2

Optimization of reaction conditions for $\mathrm{BzOH}$ oxidation.

\begin{tabular}{lcccccc} 
Entry & $\begin{array}{r}\text { Time } \\
(\mathrm{min})\end{array}$ & $\begin{array}{c}\text { Molar } \\
\text { ratio }^{\mathrm{a}}\end{array}$ & $\begin{array}{c}\mathrm{Temperature} \\
\left({ }^{\circ} \mathrm{C}\right)\end{array}$ & $\begin{array}{c}\text { Catalyst } \\
(\mathrm{mol} \%)\end{array}$ & $\begin{array}{c}\text { Yield } \\
(\%)\end{array}$ & $\begin{array}{c}\text { Selectivity } \\
(\%)\end{array}$ \\
\hline 1 & 60 & $1: 3$ & 60 & 5 & 73 & $>99$ \\
2 & 90 & $1: 3$ & 60 & 5 & 90 & $>99$ \\
3 & 120 & $1: 3$ & 60 & 5 & $93(84)$ & $75(25)$ \\
4 & 90 & $1: 1$ & 60 & 5 & 45 & $>99$ \\
5 & 90 & $1: 2$ & 60 & 5 & 62 & $>99$ \\
6 & 90 & $1: 4$ & 60 & 5 & $96(92)$ & $67(37)$ \\
7 & 120 & $1: 3$ & r.t. & 5 & 13 & $>99$ \\
8 & 120 & $1: 3$ & 40 & 5 & 48 & $>99$ \\
9 & 90 & $1: 3$ & 80 & 5 & $79(86)$ & $71(29)$ \\
10 & 90 & $1: 3$ & 60 & 1 & 54 & $>99$ \\
11 & 90 & $1: 3$ & 60 & 10 & $92(84)$ & $78(22)$ \\
12 & 90 & $1: 3$ & 60 & 15 & $82(90)$ & $65(35)$ \\
$13^{d}$ & 120 & $1: 2$ & 60 & 5 & 2 & $>99$ \\
14 & 90 & $1: 3$ & 60 & - & - & - \\
\hline
\end{tabular}

a $\mathrm{BzOH}: \mathrm{H}_{2} \mathrm{O}_{2}$ molar ratio.

${ }^{b}$ Isolated yield for BzH (benzoic acid as the main by-product).

cSelectivity for BzH (benzoic acid as the main by-product).

d ZP was used as the catalyst (blank). composition of $\mathrm{H}_{2} \mathrm{O}_{2}$ at high temperatures, leading to insufficient oxidation of BzOH (Table 2, entries 2 and 7-9). When the molar ratio of $\mathrm{BzOH}: \mathrm{H}_{2} \mathrm{O}_{2}$ reached $1: 3$, the highest yield was obtained, but on further increasing the ratio, the yield increased slightly, but the selectivity for BzH decreased sharply (Table 2, entries 2 and 4-6). The optimum reaction conditions were $60{ }^{\circ} \mathrm{C}, 1: 3$ of $\mathrm{BzOH}: \mathrm{H}_{2} \mathrm{O}_{2}$ molar ratio, 90 min (Table 2, entry 2). The oxidation reaction was also performed using ZP as the catalyst (Table 2, entry 13) and without a catalyst (Table 2, entry 14) to investigate the role of our catalyst. In both cases, no significant amount of $\mathrm{BzH}$ was detected.

As shown in Table 3, a wide range of alcohols bearing either electron-donating or electron-withdrawing groups were successfully oxidized to their corresponding carbonyl compounds, in short reaction times, using ZPCu. Efficient transformations of

\section{Table 3}

Oxidation reaction in presence of ZPCu.

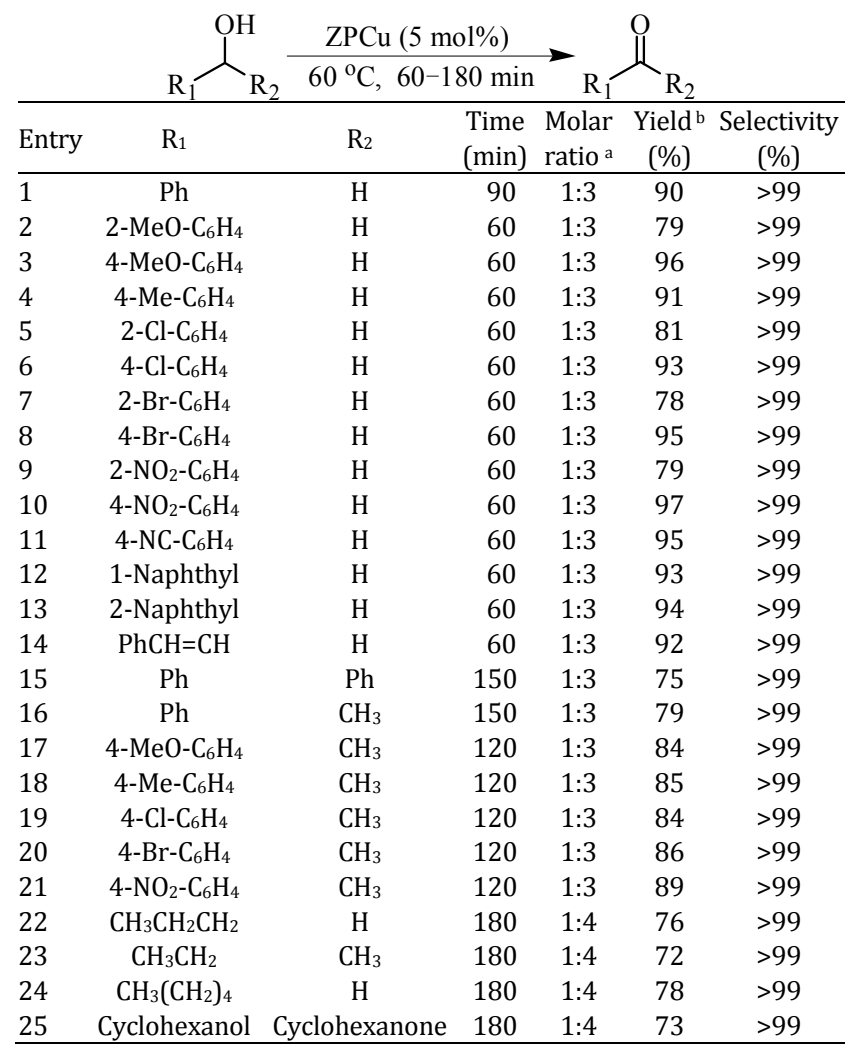

a Substrate: $\mathrm{H}_{2} \mathrm{O}_{2}$ molar ratio.

${ }^{\mathrm{b}}$ Isolated yield. All products were identified by their GC-MS and ${ }^{1} \mathrm{H}$ NMR spectra with authentic samples [13-16]. 


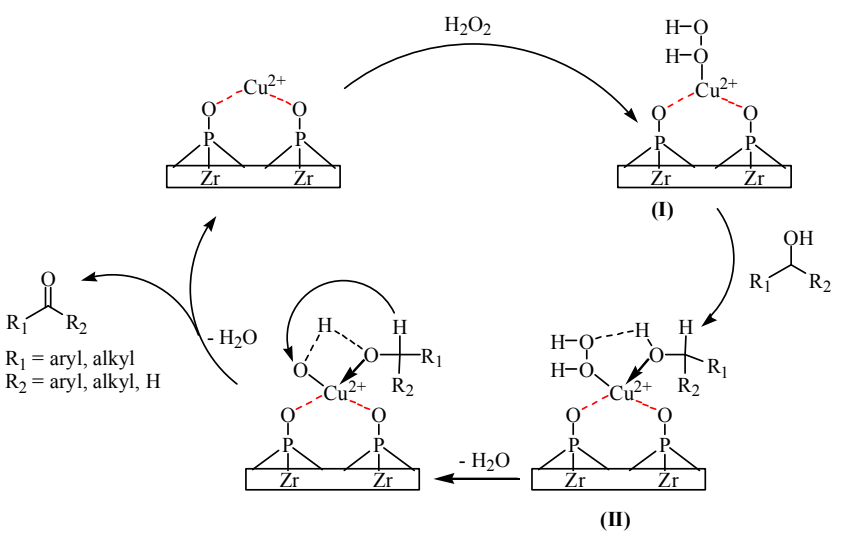

Scheme 2. Proposed mechanism for $\mathrm{ZPCu} / \mathrm{H}_{2} \mathrm{O}_{2}$ catalytic system.

primary alcohols to the desired aldehydes were achieved without any over-oxidation to the corresponding carboxylic acids (Table 3, entries 1-14).

Electron-donating and electron-withdrawing groups accelerated the oxidation reaction, but the yields obtained using ortho-substituted substrates (Table 3, entries 2, 5, 7, and 9) were lower than those obtained with the corresponding para isomer, because of steric hindrance [19,31,32]. Based on these observations, a proposed mechanism for the $\mathrm{ZPCu}$-catalyzed oxidation of alcohols with $\mathrm{H}_{2} \mathrm{O}_{2}$ is shown in Scheme 2. First, the $\mathrm{Cu}$ Lewis acid site (on the ZPCu surface) interacts with $\mathrm{H}_{2} \mathrm{O}_{2}$ to form I, which reacts with the alcohol to give intermediate II. Two hydration steps convert II to the corresponding carbonyl compound, with regeneration of the active sites. Steric hindrance around the hydroxyl group of the alcohol, caused by the presence of substituents at the ortho position (Table 3, entries $2,5,7$, and 9) or the use of more hindered secondary alcohols (Table 3, entries 15-21), results in longer reaction times and lower yields. Similar behavior has been previously reported [19,31,32].

Spent ZPCu was recovered from the reaction medium and reused, to examine the catalyst recyclability. For recycling, the catalyst was separated from the reaction mixture by centrifugation after first use, washed successively with ethanol and water, dried at $110{ }^{\circ} \mathrm{C}$ for $2 \mathrm{~h}$, and activated at $500{ }^{\circ} \mathrm{C}$ for $2 \mathrm{~h}$. The product yields obtained with spent ZPCu were similar to those obtained with the fresh catalyst up to the fourth cycle (Table 4). The chemical composition of the regenerated catalyst was determined by elemental analysis after each reaction (Table 1, entries 4 and 5). No significant changes in the composition or the environment were observed after regeneration until the fourth cycle.

All products were identified by comparison of their GC-MS (Agilent 5975C) and ${ }^{1} \mathrm{H}$ NMR spectra (Bruker-Avance AQS 400 $\mathrm{MHz}$ spectrometer; in $\mathrm{CDCl}_{3}$ ) with those of authentic samples

\section{Table 4}

Catalyst reuse under optimum reaction conditions for oxidation of $\mathrm{BzOH}$.

\begin{tabular}{lcccc}
\hline Fresh & run 1 & run 2 & run 3 & run 4 \\
\hline 90 & 90 & 87 & 84 & 70 \\
\hline
\end{tabular}

Reaction conditions: $\mathrm{BzOH} 5 \mathrm{mmol}, \mathrm{H}_{2} \mathrm{O}_{2} 0.015 \mathrm{~mol}$, catalyst $5 \mathrm{~mol} \%, 60$ ${ }^{\circ} \mathrm{C}, 90$ min.
[13-16]. ${ }^{1} \mathrm{H}$ NMR spectroscopic data of compounds from Table 3 are as follows.

PhCHO (Table 3, entry 1): $\delta=10.01(\mathrm{~s}, 1 \mathrm{H}), 7.85-7.45(\mathrm{~m}$, $5 \mathrm{H})$.

2- $\mathrm{MeOC}_{6} \mathrm{H}_{4} \mathrm{CHO}$ (Table 3, entry 2): $\delta=10.41(\mathrm{~s}, 1 \mathrm{H}), 7.82(\mathrm{~d}$, $J=8.7 \mathrm{~Hz}, 1 \mathrm{H}), 7.6-7.54(\mathrm{~m}, 1 \mathrm{H}), 7.07-7.0(\mathrm{~m}, 2 \mathrm{H}), 3.96(\mathrm{~s}, 3 \mathrm{H})$.

4- $\mathrm{MeOC}_{6} \mathrm{H}_{4} \mathrm{CHO}$ (Table 3, entry 3): $\delta=9.90(1 \mathrm{H}, \mathrm{s}), 7.85(2 \mathrm{H}$,

d, $J=8.7 \mathrm{~Hz}), 7.0(2 \mathrm{H}, \mathrm{d}, J=8.4 \mathrm{~Hz}), 3.93(3 \mathrm{H}, \mathrm{s})$.

4- $\mathrm{MeC}_{6} \mathrm{H}_{4} \mathrm{CHO}$ (Table 3, entry 4): $\delta=9.92(\mathrm{~s}, 1 \mathrm{H}), 7.75(\mathrm{~d}, J=$

$7.6 \mathrm{~Hz}, 2 \mathrm{H}), 7.32(\mathrm{~d}, J=8.4 \mathrm{~Hz}, 2 \mathrm{H}), 2.43(\mathrm{~s}, 3 \mathrm{H})$.

2- $\mathrm{ClC}_{6} \mathrm{H}_{4} \mathrm{CHO}$ (Table 3, entry 5): $\delta=10.40(\mathrm{~s}, 1 \mathrm{H}), 7.88-7.86$

(q, 1H), 7.54-7.31 (m, 3H).

4- $\mathrm{ClC}_{6} \mathrm{H}_{4} \mathrm{CHO}$ (Table 3, entry 6): $\delta=9.98(\mathrm{~s}, 1 \mathrm{H}), 7.83(\mathrm{~d}, J=$ $8.5 \mathrm{~Hz}, 2 \mathrm{H}), 7.52$ (d, $J=8.5 \mathrm{~Hz}, 2 \mathrm{H})$.

2-BrC $6 \mathrm{H}_{4} \mathrm{CHO}$ (Table 3, entry 7): $\delta=10.38(\mathrm{~s}, 1 \mathrm{H}), 7.91-7.88$ (m, 1H), 7.65 (d, J = 7.2 Hz, 1H), 7.47-7.42 (m, 2H).

4- $\mathrm{BrC}_{6} \mathrm{H}_{4} \mathrm{CHO}$ (Table 3, entry 8): $\delta=10.0(\mathrm{~s}, 1 \mathrm{H}$ ), 7.78 (d, $J=$ $8.4 \mathrm{~Hz}, 2 \mathrm{H}), 7.71(\mathrm{~d}, J=8.4 \mathrm{~Hz}, 2 \mathrm{H})$.

2- $\mathrm{NO}_{2} \mathrm{C}_{6} \mathrm{H}_{4} \mathrm{CHO}$ (Table 3, entry 9): $\delta=10.44(\mathrm{~s}, 1 \mathrm{H}), 8.14(\mathrm{~d}, J$

$=7.9 \mathrm{~Hz}, 1 \mathrm{H}), 7.98-7.96(\mathrm{~m}, 1 \mathrm{H}), 7.84-7.76(\mathrm{~m}, 2 \mathrm{H})$.

4- $\mathrm{NO}_{2} \mathrm{C}_{6} \mathrm{H}_{4} \mathrm{CHO}$ (Table 3, entry 10): $\delta=10.18(\mathrm{~s}, 1 \mathrm{H}), 8.39$ (d, $J=8.7 \mathrm{~Hz}, 2 \mathrm{H}), 8.08(\mathrm{~d}, J=8.2 \mathrm{~Hz}, 2 \mathrm{H})$.

4-NCC $\mathrm{H}_{4} \mathrm{CHO}$ (Table 3, entry 11): $\delta=10.13$ (s, 1H), 8.11 (d, $J=8.2 \mathrm{~Hz}, 2 \mathrm{H}), 7.90$ (d, $J=8.2 \mathrm{~Hz}, 2 \mathrm{H})$.

1-Naphthaldehyde (Table 3, entry 12): $\delta=10.39$ (s, 1H), $9.24(\mathrm{~d}, J=8.5 \mathrm{~Hz}, 1 \mathrm{H}), 8.11(\mathrm{~d}, J=8.5 \mathrm{~Hz}, 1 \mathrm{H}), 8.07$ (d, $J=7.3$ $\mathrm{Hz}, 1 \mathrm{H}), 7.95(\mathrm{~d}, J=8.2 \mathrm{~Hz}, 1 \mathrm{H}), 7.75(\mathrm{t}, J=7.8 \mathrm{~Hz}, 1 \mathrm{H})$, 7.65-7.56 (m, 2H).

2-Naphthaldehyde (Table 3, entry 13): $\delta=10.17(1 \mathrm{H}, \mathrm{s})$, 8.35 (s, 1H), 8.03 (d, $J=8.2 \mathrm{~Hz}, 1 \mathrm{H}), 7.98(\mathrm{dd}, J=1.3 \mathrm{~Hz}, 10.0 \mathrm{~Hz}$, 2H), 7.94 (dd, $J=8.7 \mathrm{~Hz}, 14.2 \mathrm{~Hz}, 1 \mathrm{H}), 7.66(\mathrm{t}, J=7.6 \mathrm{~Hz}, 1 \mathrm{H}$ ), 7.61 (dd, $J=7.6 \mathrm{~Hz}, 1 \mathrm{H})$.

$\mathrm{PhCH}=\mathrm{CHCHO}$ (Table 3, entry 14): $\delta=9.67(\mathrm{~d}, J=7.6 \mathrm{~Hz}$, 1H), 7.56-7.52 (m, 2H), 7.46-7.41 (m, 4H), 6.72-6.66 (m, 1H).

$\mathrm{Ph}_{2} \mathrm{CO}$ (Table 3, entry 15): $\delta=7.81(\mathrm{~d}, J=7.5 \mathrm{~Hz}, 4 \mathrm{H}), 7.59$ (t, $J=7.3 \mathrm{~Hz}, 2 \mathrm{H}), 7.49(\mathrm{t}, J=8.0 \mathrm{~Hz}, 4 \mathrm{H})$.

$\mathrm{C}_{6} \mathrm{H}_{5} \mathrm{COCH}_{3}$ (Table 3, entry 16): $\delta=7.97(\mathrm{~d}, J=7.5 \mathrm{~Hz}, 2 \mathrm{H})$,

$7.57(\mathrm{t}, J=7.5 \mathrm{~Hz}, 1 \mathrm{H}), 7.47(\mathrm{t}, J=7.5 \mathrm{~Hz}, 2 \mathrm{H}), 2.62(\mathrm{~s}, 3 \mathrm{H})$.

4- $\mathrm{MeOC}_{6} \mathrm{H}_{4} \mathrm{COCH}_{3}$ (Table 3, entry 17): $\delta=7.90$ (d, $J=9.0 \mathrm{~Hz}$,

$2 \mathrm{H}), 6.9(\mathrm{~d}, J=9.0 \mathrm{~Hz}, 2 \mathrm{H}), 3.85(\mathrm{~s}, 3 \mathrm{H}), 2.58(\mathrm{~s}, 3 \mathrm{H})$.

4- $\mathrm{MeC}_{6} \mathrm{H}_{4} \mathrm{COCH}_{3}$ (Table 3, entry 18): $\delta=7.84$ (d, $J=8.5 \mathrm{~Hz}$, $2 \mathrm{H}), 7.23(\mathrm{~d}, J=8.0 \mathrm{~Hz}, 2 \mathrm{H}), 2.57(\mathrm{~s}, 3 \mathrm{H}), 2.38(\mathrm{~s}, 3 \mathrm{H})$.

4- $\mathrm{ClC}_{6} \mathrm{H}_{4} \mathrm{COCH}_{3}$ (Table 3, entry 19): $\delta=7.92-7.88(\mathrm{~d}, J=8.4$

$\mathrm{Hz}, 2 \mathrm{H}), 7.45-7.42$ (d, J = 8.4 Hz, 2H), $2.58(\mathrm{~s}, 3 \mathrm{H})$.

4- $\mathrm{BrC}_{6} \mathrm{H}_{4} \mathrm{COCH}_{3}$ (Table 3, entry 20): $\delta=7.84-7.81$ (d, $J=8.5$ $\mathrm{Hz}, 2 \mathrm{H}$ ), 7.63-7.6 (d, J = 8.5 Hz, 2H), 2.57 (s, 3H).

$4-\mathrm{NO}_{2} \mathrm{C}_{6} \mathrm{H}_{4} \mathrm{COCH}_{3}$ (Table 3, entry 21): $\delta=8.35-8.33(\mathrm{~d}, J=$

$8.4 \mathrm{~Hz}, 2 \mathrm{H}), 8.15-8.12(\mathrm{~d}, J=8.4 \mathrm{~Hz}, 2 \mathrm{H}), 2.7(\mathrm{~s}, 3 \mathrm{H})$.

$\mathrm{CH}_{3} \mathrm{CH}_{2} \mathrm{CH}_{2} \mathrm{CHO}$ (Table 3, entry 22): $\delta=9.76(\mathrm{~s}, 1 \mathrm{H}$ ), 2.39

(m, 2H), $1.65(\mathrm{~m}, 2 \mathrm{H}), 0.97(\mathrm{t}, J=7.4 \mathrm{~Hz}, 3 \mathrm{H})$.

$\mathrm{CH}_{3} \mathrm{CH}_{2} \mathrm{CHOCH}_{3}$ (Table 3, entry 23): $\delta=2.47$ (q, $J=7.6 \mathrm{~Hz}$, $2 \mathrm{H}), 2.14(\mathrm{~s}, 3 \mathrm{H}), 1.14(\mathrm{t}, J=7.6 \mathrm{~Hz}, 3 \mathrm{H})$.

$\mathrm{CH}_{3}\left(\mathrm{CH}_{2}\right)_{4} \mathrm{CHO}$ (Table 3, entry 24): $\delta=9.81(\mathrm{~s}, 1 \mathrm{H}), 2.38(\mathrm{~m}$, 2H), $1.65(\mathrm{~m}, 2 \mathrm{H}), 1.34(\mathrm{~m}, 2 \mathrm{H}), 1.29(\mathrm{~m}, 2 \mathrm{H}), 0.95(\mathrm{t}, J=7.5 \mathrm{~Hz}$, $3 \mathrm{H})$.

Cyclohexanone (Table 3, entry 25): $\delta=2.52-2.38(\mathrm{~m}, 4 \mathrm{H})$, 2.2-1.64 (m, 6H). 


\section{Graphical Abstract}

Chin. J. Catal., 2014, 35: 1529-1533 doi: 10.1016/S1872-2067(14)60096-6

\author{
Selective oxidation of alcohols over copper zirconium phosphate \\ Abdol R. Hajipour*, Hirbod Karimi \\ Isfahan University of Technology, Iran; University of Wisconsin, USA
}

Copper zirconium phosphate was prepared and used as an efficient catalyst for the selective oxidation of various alcohols to the corresponding aldehydes and ketones, in good yields and with excellent selectivities.

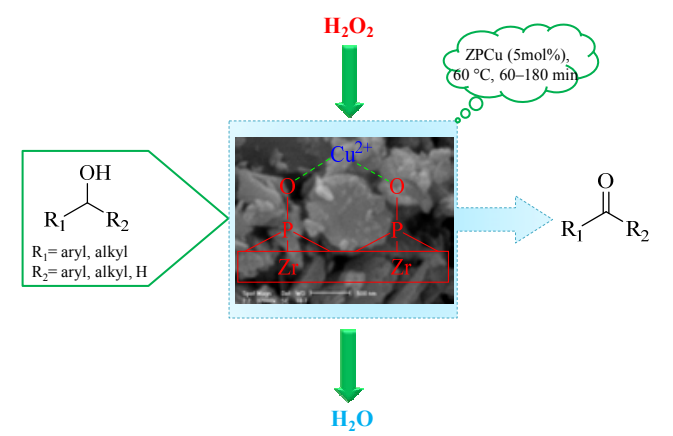

\section{Conclusions}

In summary, we have reported the catalytic performance of water-insoluble $\mathrm{ZPCu}$ in the oxidation of alcohols using $\mathrm{H}_{2} \mathrm{O}_{2}$. The catalyst was characterized using various methods and the results showed good agreement with those in the literature. ZPCu showed outstanding catalytic performance with excellent conversion of $\mathrm{BzOH}$ and selectivity for $\mathrm{BzH}$ at $60^{\circ} \mathrm{C}$ for $90 \mathrm{~min}$. The selectivity remained unchanged in all the reactions, although the conversions were affected by steric hindrance; alcohols with bulky groups required longer reaction times. This procedure is environmentally benign, general, efficient, high yielding, safe, and operationally simple.

\section{References}

[1] Li F, Wei M, He J, Du Y, Sun P, Evans D G, Duan X. Chin J Catal (李峰, 卫敏，何静，杜以波，孙鹏，Evans D G，段雪. 催化学报), 1999, 20: 510

[2] Sun L, Boo W J, Sue H J, Clearfield A. New J Chem, 2007, 31: 39

[3] Clearfield A. Chem Rev, 1988, 88: 125

[4] Shi Q S, Tan S Z, Ouyang Y S, Yang Q H, Chen A M, Li W R, Shu X L, Feng J, Fang J, Chen Y B. Adv Mater Res, 2011, 150-151: 852

[5] Cai X, Dai G J, Tan S Z, Ouyang Y, Ouyang Y S, Shi Q S. Mate Lett, 2012, 67: 199

[6] Clearfield A, Kalnins J M. J Inorg Nucl Chem, 1978, 40: 1933

[7] Clearfield A, Kalnins J M. J Inorg Nucl Chem, 1976, 38: 849

[8] Allulli S, Ferragina C, La Ginestra A, Massucci M A, Tomassini N, Tomlinson A A G.J Chem Soc, Dalton Trans, 1976: 2115

[9] Khare S, Chokhare R. J Mol Catal A, 2012, 353-354: 138

[10] Izumi Y, Mizutani Y. Bull Chem Soc Jpn, 1979, 52: 3065
[11] Khare S, Chokhare R. J Mol Catal A, 2011, 344: 83

[12] Iwamoto M, Nomura Y, Kagawa S.J Catal, 1981, 69: 234

[13] Pylinina A I, Mikhalenko I I. Russ J Phys Chem, 2013, 87: 372

[14] Pylinina A I, Mikhalenko I I. Russ J Phys Chem, 2011, 85: 2109

[15] Shirini F, Abedini M, Pourvali A. Chin Chem Lett, 2011, 22: 33

[16] Cheng X Y, Li K F, Wang Q J, Wang C Y, Ying T K. Chin Chem Lett, 2012, 23: 801

[17] Pourali A R, Tabaean M, Nazifi S M R. Chin Chem Lett, 2012, 23: 21

[18] Ahmad J U, Räisänen M T, Leskelä M, Repo T. Appl Catal A, 2012, 411-412: 180

[19] Hu Z Z, Kerton F M. Appl Catal A, 2012, 413-414: 332

[20] Furukawa S, Tamura A, Shishido T, Teramura K, Tanaka T. Appl Catal B, 2011, 110: 216

[21] Lingaiah N, Reddy K M, Babu N S, Rao K N, Suryanarayana I, Prasad P S S. Catal Commun, 2006, 7: 245

[22] Zhou X T, Ji H B. Chin J Catal (周贤太, 纪红兵. 催化学报), 2012, 33: 1906

[23] Zhang H, Fu L L, Zhong H N. Chin J Catal (张华, 付罗岭, 钟红敏. 催化学报), 2013, 34: 1848

[24] Zhang H, Liu Y, Zhang X G. Chin J Catal (张海, 刘荣, 张勋高. 催化 学报), 2011, 32: 1693

[25] Ali S R, Chandra P, Latwal M, Jain S K, Bansal V K, Singh S P. Chin J Catal (催化学报), 2011, 32: 1844

[26] Rao P S N, Rao K T V, Sai Prasad P S, Lingaiah N. Chin J Catal (催化 学报), 2011, 32: 1719

[27] Yang Y H, Dai G J, Tan S Z, Liu Y L, Shi Q S, Ouyang Y S. J Rare Earths, 2011, 29: 308

[28] Egerton T A, Stone F S. J Chem Soc, Faraday Trans 1, 1973, 69: 22

[29] Sneddon J. Biochem Pharmacol, 1987, 36: 3723

[30] Chen S B, Ma Y B, Chen L, Xian K. Geochem J, 2010, 44: 233

[31] Babu S G, Priyadarsini P A, Karvembu R. Appl Catal A, 2011, 392: 218

[32] Chen C Y, Liu B, Chen W Z. Synthesis, 2013, 45: 3387 